\title{
Award-winning paper in 2020
}

Papers published in Ground Improvement are eligible for awards from the Institution of Civil Engineers. Papers from any of the ICE journals can be nominated for several awards. In addition, each journal has awards dedicated to their specific subject area.

On Friday 15 October 2021, ICE president Rachel Skinner presented awards to the following papers published in Ground Improvement in 2020 The editorial panel nominated their best papers and an awards committee chaired by Tim Broyd allocated the awards.

\section{Telford Premium}

The Telford Premium, presented to the best paper published in Ground Improvement, was awarded to Riccio et al., (2020).

\section{Abstract}

This paper presents the site investigation and ground stiffening carried out in an $8 \mathrm{~m}$ thick, soft soil deposit located in the western zone of Rio de Janeiro, Brazil. The stiffening was achieved through the use of pre-fabricated vertical drains and radial deep consolidation grouting, a form of compaction grouting. In this study, the results of the site investigation, comprising laboratory and in situ tests, are presented and discussed. Soft soil parameters were used to compute the settlement-time curve considering vertical drains without grout injection. This was compared with the settlement-time field curve after grouting, obtained using data from settlement plates monitored for a period of $147 \mathrm{~d}$. Comparison of the two sets of data enabled an improvement factor to be determined, thus quantifying the efficiency of the grouting. Field measurements, provided by settlement plates, were extrapolated to a long-term condition. Also, the final settlement after grouting treatment was evaluated.

\section{REFERENCE}

Riccio MVF, Cirone A, Almeida MSS, Rodriguez TT and Faria DA (2020) Site investigation and performance of radial deep consolidation grouting in soft soil. Proceedings of the Institution of Civil Engineers - Ground Improvement 173(1): 28-39, https://doi.org/ 10.1680/jgrim.18.00036. 